\title{
Practical Steps to Support and Empower Diversity in the Classroom
}

\section{Yoshi Joanna Grote}

Doshisha Women's College of Liberal Arts

\section{Reference Data}

Grote, Y. J. (2021). Practical steps to support and empower diversity in the classroom community. In P. Clements, R. Derrah, \& P. Ferguson (Eds.), Communities of teachers and learners. JALT. https://doi.org/10.37546/JALTPCP2020-25

The purpose of this paper is to present an argument that because the classroom is a microculture, teachers are in a unique position to create a classroom culture that realizes the progress culture, teachers are in a unique position to create a classroom culture that realizes the progress
which society is striving toward. For this reason, the English language classroom is an ideal place to challenge gender stereotypes and collectively deconstruct some aspects of the gender binary. The first section of the paper discusses why it is necessary to heighten awareness of gender issues in the classroom in terms of both inequalities and pressures for behavior. The second section outlines four practical steps teachers can take to support gender diversity in their learning communities. First, un-gendering pedagogical practices, the language taught and used, and the materials presented. Second, creating a safe, authentic and diversity-positive culture in the classroom. Third, increasing visible support for LGBTQ+ individuals. Finally, finding a way to model an authentic comfort with difference as a teacher

教員はユニークな立場にある。何故なら教室はマイクロカルチャーであり、教員は自分たちの理想とする社会を教室文化 に反映することができるからである。このような理由から、教室はジェンダー・ステレオタイプに挑戦し、議論するのに最適な 場所だと考えられる。本稿の第一部では、ジェンダー問題に対する学生の意識を何故高める必要があるのかを論じる。第二部 では、教室コミュニティにおいて多様性を支援するために教師がとることができる四つの実践的なステップを概説する。これ では、教室コミュニティにおいて多様性を支援するために教師がとることができる四つの実践的なステップを概説する。これ
らのステップとは、第一に、教材・使用言語・指導方法において性による偏見を無くす、第二に、教室内に安全で本格的かつ多 様性を肯定する文化を作り上げる、第三に、LGBTQ+の人びとへの目に見える支援を增やす、そして最後に、教員として他者と 様性を肯定する文化を作り上げる、第三に、LGBTQ+の人びとへの目に見える支援を増やす、そして最後に、教員 s children dream of their futures, some wear crowns or stethoscopes and some tie sheets around their shoulders and stretch out their arms as superheroes. I, with my feet planted firmly on a table, watched Dead Poet's Society and quoted, "Oh Captain, my Captain!" I am sure this is a familiar narrative for many teachers - we have our favorite teaching films from when we were young. One thing we may notice from these films is that the classroom is the focal point and in essence, the students' entire world. In Dead Poet's Society, everything the boys were thinking and becoming and the values they were creating, happened in the classroom. This is because the classroom, made right, can be a micro-culture built to reflect societal goals for progress. As individuals may differ in their understanding of the meaning of progress, it may be useful to look to external organizations for goals that are largely agreed upon as necessary for global advancement. The United Nations is considered to be an intergovernmental organization working toward global development. The United Nations 17 Sustainable Development Goals (SDGs) were created with the stated aim of promoting prosperity and economic growth while protecting the planet and addressing a range of social needs (https://www. un.org/sustainabledevelopment/). The fifth SDG is listed as Gender Equality and the Empowerment of Women. To progress toward equality and empowerment, people must first be made aware of the issues involved. Gender, by its nature, is inexorably linked to the human experience and without explicit deconstruction can often be misunderstood as a natural condition. With this in mind, this paper is divided into two sections. The first makes the case for a societal need for progressing gender equality and why it is necessary to reflect this and deconstruct gender in the English language classroom. The second section outlines some practical steps for how it can be done.

\section{Progress toward Gender Equality}

There is a growing global understanding that addressing gender inequality is not only for the benefit of women, but necessary to improve the lives of all members in society. According to the World Economic Forum Global Gender Gap Report (2019): 
Gender parity has a fundamental bearing on whether or not economies and societies thrive. Developing and deploying one-half of the world's available talent has a huge bearing on the growth, competitiveness and future-readiness of economies and businesses worldwide.

The Global Gender Gap Index (World Economic Forum, 2019) benchmarked 153 countries from first (smallest gender gap) down to number 153, with the largest gender gap. Using the four indices of economic participation and opportunity, educational attainment, health and survival, and political empowerment, the report projected that if progress continues at its current pace, gender parity will not be reached for 99.5 years. At the time of writing, Iceland ranked first in the report, whereas Japan ranked 121 out of the 153 participating countries. Only $5 \%$ of people serving on corporate boards in Japan are women, and women are hugely under-represented in Japanese politics (World Economic Forum, 2019). As teachers, we are in the business of the future-readiness of our students. It stands to reason, therefore, that we address gender parity in our classrooms as well.

\section{Awareness Is Empowering}

The first reason teachers need to build students' awareness of gender issues is because gender is an invisible social construct that affects all students. It affects them in terms of how they are expected to behave and also in terms of the opportunities they will be afforded. One hundred years has not yet passed since women gained the right to vote in Japan. However, students commonly seem to feel they are living in a post-equality age where both women and men are empowered and speaking of gender is passé. As Walters (2005) lamented at the end of her A Very Short Introduction to feminism, young people "... seem uninterested in feminism, partly because they see it simply as an academic subject something fed to them, which they need not discover for themselves - and it is therefore respectably dull" (p. 140). Equally, in her short text We Should All be Feminists, Adichie (2015) stated:

I often make the mistake of thinking that something that is obvious to me is just as obvious to everyone else. Now, take my dear friend Louis for example. Louis is a brilliant, progressive man, and we would have conversations and he would tell me, "I don't know what you mean by things being different or harder for women. Maybe in the past, but not now." (p. 4)
As can be seen from these quotes, two assumptions are often made about gender. One is that gender equality has been reached. It is clear from the Global Gender Gap Index that this is not the case. The second is that gender is synonymous with women's issues. This is also not true.

Students need to be made aware of the fact that gender limits men as well. Masculinity tends to be given higher value in society and for this reason, women are afforded a greater span of movement along the gender spectrum. To a certain extent, a woman exhibiting traditionally "masculine" behaviors or moving into male roles is applauded: female doctors, soccer players, and lawyers may hit a glass ceiling but be generally regarded as "moving up." On the other hand, men who attempt to move into stereotypically feminine roles are considered to be "moving down" and therefore meet much resistance from those around them. This is why it may be hard to be a stay-athome father, a male ballet dancer, or nurse. One of my male students wanted very much to be a flight attendant. At the job-hunting sessions, potential pilots were required to stand in one line while flight attendants were asked to gather in another. He was repeatedly told that he was standing in the wrong line. On the rare occasions when he made it to the interview stage, the first question he was reportedly asked was, "Why do you want a woman's job?" After many rejections, he finally secured a place with an airline that had instituted a policy of having one male flight attendant on each long-distance flight. I asked him if he knew the reason for the new policy and he said he thought it had to do with carrying heavy bags.

Students also need to recognize that the world around them is gender binary. It pressures humans into certain behaviors and assigns expectations based on gender. Evidence can be found in toy shops, in how far men and women are expected to run in sports class, how skilled at math or writing students are expected to be and what ratios of strength, caring, ambition and parenting instinct they are expected to have or obtain. The gender binary affects how comfortable people feel ordering a fruity cocktail or knitting in public, how people walk, shave, wear their hair, use language, and express anger or sadness. It affects the clothing choices, greetings and all-you-caneat or drink prices, just to name a few examples. Often the binary is so ingrained in the understanding of society that it feels "natural", and it can therefore be difficult to critically deconstruct. As Lorber (1994) famously said,

Talking about gender for most people is the equivalent of fish talking about water. Gender is so much the routine ground of everyday activities that questioning its taken-for-granted assumptions and presuppositions is like thinking about whether the sun will come up. (p. 13) 
To empower students to be able to make informed decisions about their own gender performances and expressions, teachers must raise their awareness of the water.

\section{How Can Teachers Deconstruct Gender in the Classroom?}

The next section of this paper has been informed by the voices of students and therefore includes multiple quotes. For this reason, I would like to explain how these quotes were obtained.

\section{Data Source}

The quotes included in the following section are from undergraduate students and they were collected between July 2012 and July 2020. Some of the quotes included in this paper come from end-of-semester focus-group feedback collected in an advanced (English) level gender studies class. Students were placed into groups of three or four with one student taking the role of moderator. Set questions about class satisfaction, personal challenges and learning achievements and classroom environment were discussed in English by the students in their groups and recorded. The focus-group feedback took roughly 80 minutes. These voice files were later transcribed.

Other quotes included in this paper come from face-to-face interviews with LGBTQ+ students. A predictable outcome of being an openly gay teacher is that LGBTQ+ student often make themselves known to me. I became interested in how these students conceptualized their own identities in the context of the university campus and English language classroom. For this reason, I conducted one-to-one interviews on campus with 20 students who had come out to me and were willing to participate in the research. Interviews were semi-structured with 12 questions core questions and sub-questions added where further detail was useful. Interviews lasted between 60 and 90 minutes, were conducted in English, recorded and transcribed. Participants were almost exclusively "advanced" level in our program, meaning they had an IELTS score over 5.5 (or equivalent) and a high level of general English fluency. However, any areas where meaning was unclear were sent back to interviewees for clarification. Students who agreed to be interviewed were informed of the purpose of the research both verbally and in writing. Before being interviewed, students read and signed consent forms that were available in both English and Japanese. All the participants of both focus-group feedback and interviews gave informed consent, and the project was cleared with the university's institutional review board. All quotations used in this paper are kept in their original form to best represent the students' voices. This means quotations occasionally include contractions and grammatical errors. To protect student privacy, no names are given. Participants are listed as "interviewee" if the quote was obtained during a one-to-one interview and "gender studies student" if the quote was obtained during focus-group feedback.

\section{Invisible LGBTQ+}

The second reason teachers need to build awareness of gender is to better support the LGBTQ+ students in classes. Although many students are attracted to English because of the culture of "difference", LGBTQ+ students often mention English as a space in which they imagine they may receive greater acceptance. This is clear in the words of one interviewee:

Japanese thinking is that we are the same and we can't be outsiders. So LGBTQ+ people are different from us so they gonna feel like we can't accept them. So that society makes it is hard to come out... but I came out only to friends in the foreign languages department so they may understand different cultures or have a large point of view. If I come out my sexuality to other people, not in the foreign language department, they might not understand me. (Interviewee 1)

Another student echoed this sentiment of coming out to someone who is also connected to the study of foreign languages by saying, "I first came out to my best friend from high school. She studies English and she understands me very well." (Interviewee) Other LGBTQ+ students mention a connection between learning about their identity and the language of English:

And I was like, what am I? And also, like scared, like I'm different from others and then... I think I studied English and got to know about this kind of thing online and that helped me to feel like, you know... (Interviewee 2)

Still others connect the study of English with their future plans and assumptions about the acceptance of their identity both in Japan and overseas:

I want to have a baby, so I thought I need to study English to live in another country. In Japan, LBGT is not so well known so... so I entered this university to study English and I started to save money for study abroad cost. But if my family reject me, it's gonna be tuition for this university and I'm gonna give up to go overseas. (Interviewee 3)

The student interviewee above mentioned LGBT topics being "not so well known" in Japan. This may be linked to a lack of visibility due to cultural factors such as collectivism 
(Hofstede, Hofstede \& Minkov, 2010; Triandis, 2018), which can make people wary of standing out from the group, and high-context communication (Hall, 1989, 1990; Kittler et al., 2011), which may make the direct action of "coming out" more difficult. These factors combined with the centrality of (heterosexual) marriage as an organizing principal of society contribute to the invisibility of LGBTQ+ identities and queer dialogue in society.

Although society is organized in a gender binary way, individuals are not gender binary; that includes the reader of this paper, your students and the LGBTQ+ teachers and students in your educational institution. If teachers are reflecting goals for societal progress in classrooms, it makes sense to include deconstructing the gender binary and increasing gender representations.

\section{Practical Steps}

In the next section, I would like to outline four steps teachers can adapt to their contexts.

\section{Step 1: Ungender Your Classroom \& Diversify Your Materials}

In my opinion, there is no good reason to divide students by gender. Japanese is quite a gendered language with word choice, intonation and sentence end particles often determined by the speaker's gender. For this reason, it may initially make sense that some teachers of Japanese ask women to sit on one side of the class, and men on the other, while teaching different forms of the language. However, this method presumes that a non-native learning Japanese would rather speak correctly in terms of language and grammar usage than in a way that best matches their expression of masculinity or femininity. This is not always true, especially, but not limited to, the case of transitioning transgender students and non-binary individuals. Equally, in any language, there is no need to ask students to read dialogues in a way that matches their supposed gender expression or to pair or group students based on this.

In addition, it is natural for teachers to have their own biases but equally imperative to become conscious of them. It may be tempting, for example, after hearing several female students voice their opinion about a particular topic, to call upon a student to give a "male perspective." However, by doing so teachers not only reveal the bias that they expect men to think differently from women on a particular topic, but also assign a gender identity to a student. If a teacher is not completely sure how a student identifies, it may be safer to simply ask, "What do you think?"
Another way that teachers can "ungender" is to heighten their own awareness of the language taught and used in the classroom environment. If language shapes thought, language teachers can be on the forefront of how language is evolving to become more gender neutral. The London Underground made headlines in 2017 (Lees, 2017) when it decided to stop using the phrase, Ladies and Gentlemen in favor of the more inclusive, Hello Everyone. This move was followed by JAL (The Japan Times, 2020) and Air Canada (Ma, 2019) and it therefore stands to reason that teachers follow suit. Many textbooks have updated occupational terms such as fireman, policeman, waitress, stewardess to the more neutral terms of firefighter, police officer, server, and flight attendant but if a teacher comes across an outdated term, they can address it and explain why it has changed. Teachers can also ask students to consider gendered terms in their own languages, such as a close look at how the kanji for nurse(看護婦, kangofu) and birth attendant (助産婦, josanpu) have both evolved to remove the kanji for woman (女). The gender neutral terms are now 看護師 (kangoshi) and 助産師 (josanshi) respectively.

Although occupational terms have been widely updated, gender bias in textbooks is not entirely a thing of the past. Cook's (2015) analysis of text and image in the English language textbook, Stretch (Stempleski, 2014) found evidence of gender bias in terms of frequency of male representation over female representation, and in terms of interactions (women were often in situations asking for help, for example). In two of the chapters, People We Admire and Music, women were also significantly under-represented. When instructors find such bias in a textbook they are using, these can be used as a springboard for students to discuss stereotypes, where they come from and the extent to which they are "true" (see Nagatomo, 2011 for further details of how to lead students through effective analysis).

This kind of explicit focus on gender representation in materials can be empowering for students, but it is also important to diversify the materials presented in a class as much as possible. For students to effectively learn a language, they should feel they are represented. For this reason, it is imperative to choose TedTalks, film, text and other resources with this in mind. PowerPoint is another, often overlooked, resource. Many teachers use PowerPoint to support their pedagogical approach in the classroom. The images chosen for PowerPoints can be a powerful way of challenging stereotypes. However, questioning the status quo needs intention. If a teacher simply chooses one of the first hits an image search for athlete returns, for example, they will almost certainly get a man. Likewise, a search for parent will most probably result in a female representation as will googling the verb, to knit. The adjective affectionate may come back 
with images of heterosexual couples but by being explicit about choices of these images for slides, teachers can wordlessly challenge gender stereotypes.

\section{Step 2: Build an Authentic and Diversity-Positive Classroom Culture}

When teachers are asked what kind of classroom environment they endeavor to create, key words such as comfortable, open, safe, brave often come high on their lists, yet students do not automatically appear at the door ready to share experiences and challenge fixed mindsets. Actively building a cohesive, united classroom culture that is diversity-positive is key to creating a supportive environment. One way this can be done is by replacing the standard, "What did you do over your weekend?" warm up with either a team-building or self-disclosure activity.

The internet is a rich resource when it comes to finding team building activities and so many of them can be completed in 10-15 minutes and completely shift the atmosphere of the classroom. For example, shortly after taking attendance, students can be taken outside to untangle themselves from a "human knot" or given 15 minutes to design and build a spaghetti and marshmallow tower with group members. Team building is successful because it shifts the focus from academic skills to collaboration and leadership. It gives students the chance to display different strengths and therefore helps level the playing field.

Self-disclosure activities can also be extremely effective in bringing students closer together. A student favorite is an activity based on a TV Denmark advertisement (TV2Danmark, 2017) called All that we share. In the advertisement, a voice can be heard reading out various sentences while participants step into the circle whenever a statement is true about them. In this way, people who were previously separated by career, status, background and other factors, find similarities amongst themselves. In the classroom, I show students this video and then ask them to write one to three statements that they would be willing to disclose about themselves. The balance is key. I tell them the statement should disclose more than what they ate for breakfast, but should not be so personal that it keeps them awake the night before the class. I collect these sentences, correct the language and place them on a PowerPoint. The statements are all anonymous. The following week, we get in a large circle. I read out each sentence (each also appears on the PowerPoint to give additional language support) and we step into the circle for those that are true about ourselves. The statements have ranged from the funny, I still pick my nose to the more serious My father died when I was a child. Some rules are important here. First, I do not think it is fair to ask students to participate in any team building or self-disclosure activities that I would not be comfortable doing myself and for that reason, I participate too. Second, I tell students they are always free to opt out of any of these activities and $\mathrm{I}$ am explicit in how to do so. For this one, opting out involves standing in the circle, but not stepping into the middle for any of the statements. Third, I make the rules of the activities very clear before starting. For this activity, they include: 1) You do not have to step into the circle if you are not comfortable disclosing the truth about yourself, even if you wrote the statement; 2) You cannot push anyone else into the circle; and, 3) It is a silent activity. After the activity is complete, I give students a further five minutes to talk in small groups and reflect on the experience. In the gender studies class end- of-semester focus-group feedback, students often mention this activity as the turning point for when they felt they started to come together as a class. For that reason, this activity works well between the third and fifth weeks of the semester. Teachers know that the value of building an honest and authentic environment is that it is conducive to a deeper, more transformative learning.

\section{Step 3: Increase Visibility of LGBTQ+ Support}

In the years of interviewing LGBTQ+ students at my university, the number one request which surfaced was increased awareness of gender topics in general. The second was increased visibility of LGBTQ+ identities. In the words of one student:

Something that would have helped me in my most insecure times is a series of posters hung up on campus that, for example, by educating on LGBTQIA+ issues, show not only the university's recognition of the community but also its acceptance. (Interviewee)

Teachers do not always have the power to implement this kind of explicit visibility on an institutional level, but many are able to do so as individuals. Some examples include safe space stickers on offices, LGBTQ+ pride stickers on laptops, open anti-discrimination statements on syllabi or classroom rules slides, explicit opportunities for pronouns to be listed and anonymous surveys giving students occasions to reach out to the teacher with specific requests regarding their identity. These small gestures can have powerful affects. One of my co-workers, an ex-rugby-playing male who could be considered somewhat intimidating by a student who did not know him well, has a very small LGBTQ+ pride sticker on the back of his laptop. In the years I have been interviewing LGBTQ+ students at our university, almost all of them have mentioned noticing this sticker, although most have never taken his classes and do not know his name. Another coworker shared how a young transgender person had been positively affected by receiving an email from 
someone who had listed their pronouns in their email signature, which is an email footer that provides the recipient with additional information about the sender. Such small gestures as these can have a significant impact.

\section{Step 4: Model a Comfort with Difference}

Avril Haye-Matsui (2020), recently wrote a chapter entitled, Black, British and Female in the Japanese University English Classroom. There she discussed the intersectionality of race and gender and how being visibly willing to weave her personal experiences of these together with theory she is presenting to her students, has deepened student curiosity and understanding, as well as making them braver to share their own differences with her. Haye-Matsui wrote, "Another way that my gender and race intersects in positive ways with students is that it creates a space for people who may feel "different" or "marginalized" (p. 217). This is consistent with Goldstein and Benassi (1994) who argued, "...a self-disclosing teacher engenders trust and, therefore, invites participation from the students" (p. 215). Both Avril and I have experienced how being willing to openly discuss the ways in which we stand out as different has had the effect of drawing students to us to share their own differences, even when their differences do not match our own.

You do not have to be gay or a person of color to be authentic in the classroom. Teachers are unique in a myriad of ways and what they share does not have to feel like something that is a cross to bear. For example, a colleague makes trifles and brings them to her class when discussing British food culture. Another colleague is willing to answer student questions about why he is a vegetarian, and another is comfortable discussing his tattoos. Poet, spoken-word artist and singer song writer, Phil Norton teaches a unit to his students about identity. To support the content in an authentic way, he brings in his guitar and sings the song he wrote about finding home in a person rather than a place entitled, Will You Be My Home. He finds that when he shares his feelings about a lack of a traditional sense of home, his students are more able to open up about their own identities. Authenticity breeds authenticity, but why should teachers be concerned with their students' authenticity in the classroom? It is my belief that just as teachers can be more engaging when they teach with stories, students can learn more deeply when they connect content with their own personal lives. Students can learn a lot through the stories other students share in the classroom, giving a real-life application to the content. For example, one of my gender studies students reflected upon a moment when another student in the class had shared an experience by saying:
When I read the articles, I always thought, "Is that really a problem that you treat boys a certain way and girls a certain way, is that a problem?" But when I heard you talking about how your father treats you and that you feel uncomfortable with it, that's when I thought, "Yes, we should change that."(Gender Studies Student)

To create a classroom environment where students are comfortable enough to share their own personal lives, teachers need to be explicit in creating the classroom culture.

\section{Conclusion: Teaching Is a Political Act}

While reading the above section about actively questioning representations present in existing materials, adding visibility of diverse individuals, families and couples to materials and explicitly signaling support for LGBTQIA+ people in the classroom, many teachers may understandably start to feel a line has been crossed. Is the teacher not supposed to be impartial? Are these opinions simply too political for the classroom? This resonates deeply with me too, as an educator, as for much of my career I also felt that a teacher should merely be the guide; a facilitator for critical thought but someone who left their own opinions at the door. However, I have now come to the conclusion that this concept is an impossibility and perhaps not even ideal. An impossibility because teachers bring their values and viewpoints into the classroom with every choice they make; in the videos, materials and texts they show, and in those they choose to omit. For example, a teacher who walks into a classroom with their own tumbler, who instructs students to submit assignments electronically because their classroom is "paperless" and who shows a Greta Thunberg speech is bringing their environmentalism into the classroom. Educators are human and artificially attempting to rid ourselves of our values may have little affect other than stripping ourselves of a little humanity. Certainly, without acknowledging that we bring our values and views to the class, we risk presenting them as universal, perhaps misusing our position. It is fairer then, perhaps, to explicitly frame these perspectives as our own and also empower our students in the art of discussion and criticism. If teachers recognize that part of our job is to train students to question, presenting them with a framework should not be seen as dangerous, but as an opportunity for practice.

The society we live in is more binary than the individuals within it. Pressures placed on each person to conform to expectations for gendered behavior can be exhausting and inequality of opportunity can be frustrating. As we work toward change in society, we can recognize that the classroom is a nexus for this change. By increasing students' awareness of gender issues, we empower them and by casting a critical eye over the 
materials we use to teach language, we better represent the diversity of humans we have in our classes.

\section{Bio Data}

Yoshi Joanna Grote is an assistant professor in the English Department of Doshisha Women's College of Liberal Arts. Her research interests include: 1) The visibility / invisibility and sense of belonging of LGBTQ+ students in classes and on campus and the creation of diversity-positive spaces; 2) The intersection of language, intercultural training and positive psychology with a focus on building cohesive classroom cultures conducive to deep learning.

\section{References}

Adichie, C. N. (2015). We should all be feminists. Anchor Books.

Cook, M. (2015). Gender bias in ESL/EFL textbooks: 10 years later. Between the Keys: A Publication of the JALT Materials Writers SIG, 23(3), 4-7.

Hall, E. T. (1989). Beyond culture. Anchor Books.

Hall, E. T. (1990). The silent language. Anchor Books.

Haye-Matsui, A. (2020). Black, British and female in the Japanese university English classroom. In D. H. Nagatomo, K. A. Brown, M. L. Cook, \& A. Simon-Maeda. (Eds.), Foreign female English teachers in Japanese higher education: Narratives from our quarter (pp. 206 - 222). Candlin \& Mynard Publishing Limited.

Hofstede, G., Hofstede, G.J., \& Minkov, M. (2010). Cultures and organizations: Software of the mind ( $3^{\text {rd }}$ ed.). McGraw-Hill.

Gender equality and women's empowerment | Department of economic and social affairs. (n.d.) Retrieved March 10, 2021, from https://sdgs.un.org/topics/gender-equality-and-womensempowerment

Goldstein, G. S., \& Benassi, V.A. (1994). The relation between teacher self-disclosure and student classroom participation. Teaching of Psychology, 21(4), 212. https://doi.org/10.1207/ s15328023top2104_2

Kittler, M. G., Rygl, D., \& Mackinnon, A. (2011). Beyond culture or beyond control? Reviewing the use of Hall's high-/low-context concept. International Journal of Cross-cultural Management, 11, 63-82. https://doi.org/ 10.1177/1470595811398797

Lees, P. (2017). TfL scrapping "ladies and gentlemen" isn't about trying to abolish gender. Retrieved December 23, 2020, from https://www.theguardian.com/commentisfree/2017/jul/14/all

Lorber, J. (1995). Paradoxes of gender. Yale University Press.
Ma, A. (2019, October 15). Air Canada will no longer call passengers "ladies and gentlemen," and will use the gender-neutral term "everybody" instead. Retrieved December 23, 2020, from https://www.businessinsider.com/air-canada-stop-ladies-and-gentlemen-replace-genderneutral-everybody-2019-10

Nagatomo, D. H. (2011). A critical analysis of gender representation in an EFL textbook. Journal of the Ochanomizu University English Society, 1, 53-61.

Norton, P. (n.d.). Phil Norton aka Preachermansays. Retrieved January 5, 2021, from https://www. preachermansays.com/

Stempleski, S. (2014). Stretch. Oxford University Press.

The Japan Times 2020, September 29). Japan Airlines ditches "ladies and gentlemen" for gender-neutral greetings. Retrieved December 23, 2020, from https://www.japantimes.co.jp/ news/2020/09/29/business/corporate-business/japan-airlines-jal-gender-neutral-greetings/

Triandis, H. C. (2018). Individualism and collectivism. Routledge.

TV2Danmark. (2017, January 27). TV 2 | All that we share. Retrieved January 5, 2021, from https:// www.youtube.com/watch?v=jD8tjhVO1Tc

United Nations Sustainable Development - 17 goals to transform our world. (n.d.). Retrieved March 17, 2021, from https://www.un.org/sustainabledevelopment/

Walters, M. (2005). Feminism: A very short introduction. Oxford University Press.

World Economic Forum. (2019). Global gender gap report 2020. Retrieved March 10, 2021, from https://es.weforum.org/reports/gender-gap-2020-report-100-years-pay-equality 